Prospective Evaluation

\title{
A Prospective Evaluation of Psychotherapeutic and Illicit Drug Use in Patients Presenting with Chronic Pain at the Time of Initial Evaluation
}

Laxmaiah Manchikanti, MD ${ }^{1,2}$, Kimberly A. Cash, $\mathrm{RT}^{1}$, Yogesh Malla, MD',

Vidyasagar Pampati, $\mathrm{MSc}^{1}$, and Bert Fellows, $\mathrm{MA}^{1}$

From: 'Pain Management Center of Paducah Paducah, KY; and 'University of Louisville, Louisville, KY

Dr. Manchikanti is Medical Director of the Pain Management Center of Paducah, Paducah, KY, and Clinical Professor,

Anesthesiology and Perioperative Medicine, University of Louisville, Louisville, KY.

Kimberly A. Cash is a Research Coordinator at the Pain Management Center of Paducah, Paducah, KY.

Dr. Malla is an Interventional

Pain Physician at the Pain Management Center of Paducah, Paducah, KY. Vidyasagar Pampati is a Statistician at the Pain Management Center of Paducah, Paducah, KY. Bert Fellows is Director

Emeritus of Psychological Services at the Pain Management Center of Paducah, Paducah, KY.

Address correspondence: Laxmaiah Manchikanti, M.D. 2831 Lone Oak Road

Paducah, Kentucky 42003 E-mail: drlm@thepainmd.com

Disclaimer: There was no external funding in the preparation of this manuscript.

Conflict of interest: None.

Manuscript received: 1-3-2013 Accepted for publication: 1-10-2013

Free full manuscript: www.painphysicianjournal.com
Background: Reports of chronic pain and associated opioid use, abuse, and fatalities continue to increase at an alarming rate, not only in the United States but also across the globe. In light of the many resultant fatalities, multiple authors and authorities have cautioned against the excessive use of opioids. Consequently, the Food and Drug Administration, Drug Enforcement Administration, and multiple state authorities have been proposing and implementing a plethora of regulations to curb opioid overuse and abuse. In the majority of cases, pain physicians have been portrayed as the perpetrators responsible for escalating use and abuse and resultant fatalities.

Objectives: To assess the patterns of psychotherapeutic drug use and illicit drug use at the time of initial evaluation.

Study Design: A prospective evaluation.

Setting: A private, specialty referral interventional pain management clinic in the United States.

Methods: Participants were all new patients presenting to interventional pain management evaluated by one physician. Inclusion criteria was patients over 18 years of age with chronic spinal pain of at least one year duration.

Results: The results of this evaluation indicate that $94 \%$ of patients were on long-term opioids prior to presenting to interventional pain management. Illicit drug use is also common, although it has declined significantly. While a large proportion of individuals $(45.7 \%)$ have used illicit drugs at some point in the past, current illicit drug use is present in only $7.9 \%$ of patients, both past and current use are similar to that of the general population. More importantly, a significant proportion of patients have been on opioids (high doses of more than $40 \mathrm{mg}$ equivalents of morphine $48.8 \%$ ) on a long-term basis, initiated and maintained by primary care physicians, prior to presenting to interventional pain management. Further, $35 \%$ were on benzodiazepines, and $9.2 \%$ on carisoprodol prior to presenting to interventional pain management.

Limitations: The limitations of this evaluation include that it is a prospective, single center evaluation by one physician that is partially dependent on subjective recall of the patient.

Conclusion: This study shows an overwhelming majority of patients were initiated and maintained with opioids in managing chronic noncancer pain. They were frequently on high doses over a long period of time with multiple drug combinations prescribed by primary care physicians.

Key Words: Chronic pain, persistent pain, noncancer pain, controlled substances, substance abuse, prescription drug abuse, opioids, prescriptions, urine drug testing, fatalities, regulations

Pain Physician 2013; 16:-E1-E13 
R eports of escalating chronic pain in the United States and globally continue to emerge (16). Similar to the prevalence of chronic pain, the financial costs, health care costs, and disability secondary to chronic pain continue to escalate in conjunction with numerous diagnostic and treatment modalities with related complications in epidemic proportions (4-47). Even though there is an escalation in the utilization of all types of interventions, opioids have taken a central role (31-35,48-86). The Institute of Medicine (IOM) committee reported that when opioids are used as prescribed; they will most likely be safe and effective for acute postoperative pain, procedural pain, and in patients nearing the end of life who desire more pain relief (1).

However, in contrast, the IOM committee has acknowledged the existence of a serious crisis in the diversion and abuse of opioids and a lack of evidence for the long-term usefulness of opioids in treating chronic pain. Increases in the prevalence of chronic pain, health care costs, and adverse consequences due to opioid use have caused the opioid crisis to escalate across the globe (1-6,31-35,48-87). The results of the $2010 \mathrm{Na}$ tional Survey on Drug Use and Health (NSDUH) (80), an annual survey sponsored by the Substance Abuse and Mental Health Services Administration, showed that an estimated 22.6 million, or $8.9 \%$ of Americans, aged 12 or older, were current (past month) illicit drug users. Illicit drugs include marijuana, cocaine, heroin, hallucinogens, inhalants, or prescription-type psychotherapeutics (defined in this survey as prescription-type pain relievers, tranquilizers, stimulants, and sedatives) used nonmedically. Marijuana was the most commonly used illicit drug, with 17.4 million current past month users, constituting $6.9 \%$ of the United States population. Overall, from 2002 to 2010 there has been a decrease in cocaine use, but an increase in the current use of all other illicit drugs and marijuana, without any change for psychotherapeutics or hallucinogens.

Of primary concern, however, is the fact that the use of therapeutic opioids is escalating (33), specifically in high doses over long periods of times or even lifetime use, and that these long-acting drugs. and a combination of long and short-acting drugs continue to have serious consequences including fatalities, increased health care costs and economic stability. The data overwhelmingly suggests that the increased supply of opioids, high medical users, doctor shoppers, and patients with multiple comorbid factors contribute to the majority of fatalities $(33,81) .60 \%$ of fatali- ties are among individuals receiving prescription drugs $(33,81)$.

The quadrupled sales of opioid analgesics between 1999 and 2010 are a perfect example of the therapeutic opioid explosion. The data on sales and distribution of opioids show an increase from $96 \mathrm{mg}$ morphine equivalents per person in the United States in 1997 to $710 \mathrm{mg}$ per person in $2010(81,82)$. This has been estimated to be the equivalent of $7.1 \mathrm{~kg}$ of opioid medication per 10,000 persons, or enough to supply every adult American with $5 \mathrm{mg}$ of hydrocodone every 8 hours for 47 days. Sales of hydrocodone have increased by $280 \%$ from 1997 to 2007, whereas methadone usage has increased 1,293\% and oxycodone usage by $866 \%$ (33). In addition, the estimated number of prescriptions filled for opioids exceeded 256 million in the United States in 2009, with 234 million prescriptions for immediate release (IR) opioids and 22.9 million for extended release (ER) opioids with a significant increase from 21.3 million for ER opioids and from 223.9 million for IR opioids from 2007 (83-85). Among these drugs, from 2006 through 2011 hydrocodone was still the number one prescription (86).

Unfortunately, gram per gram, people in the United States consumed more opioid medication than any other nation worldwide. Public opinion rests on the belief that pain physicians are responsible for the escalating use of opioids, and this belief has resulted in the implementation of multiple regulations (88). The data (84), however, shows that pain physicians are responsible for only $6 \%$ of prescriptions for IR opioids and $44 \%$ of prescriptions for long acting opioids. The majority of prescriptions are from medical providers including nonphysician providers. Numerous studies have illustrated that opioid prescriptions in patients outside pain management clinics and $90 \%$ of the patients in pain management clinics to be on opioids $(31-33,67-86,89)$.

It has also been shown that the majority of patients prior to presenting to pain clinics are already on opioids. It is well known that opioids also function as a gateway to abuse patterns and that they are extremely difficult to be taken off or weaned off of. In fact, Manchikanti et al (89), in 2004 in assessing patterns of illicit drug use and opioid abuse in patients with chronic pain at initial evaluation showed that of the $90 \%$ of patients who were already taking opioids, $23 \%$ were using illicit drugs, and $12 \%$ were using nonprescription opioids. In addition, in 2011 Deyo et al (77) reported the results of an analysis of electronic data from over 25,000 eligible patients, with $61 \%$ receiving a course of opioids, and with $19 \%$ of patients being long-term us- 
ers. Among the long-term opioid users, 59\% received only short-acting drugs; $39 \%$ received both long and short acting drugs; and $44 \%$ received a sedative hypnotic. Of those with any opioid use, $36 \%$ had visited a hospital emergency department. They concluded that prescription opioids were common among primary care patients with back pain. Moreover, the prevalence of psychologic distress, unhealthy lifestyles, and health care utilization increased incrementally with the duration of use. Multiple issues have been described in reference to long-term opioid use in primary care and other settings $(31-33,69-86)$. In the past decade or so, the epidemic of opioid abuse has been brought to the forefront, resulting in numerous policies affecting opioid prescriptions $(33,81)$.

We have undertaken a prospective evaluation to assess the patterns of psychotherapeutic drug use and illicit drug use at the time of initial evaluation at a private, specialty referral interventional pain management clinic in the United States.

\section{Methods}

This study was undertaken in a private, specialty referral interventional pain management clinic in the United States. The protocol was approved by the Institutional Review Board. This study was conducted with the internal resources of the practice; there was no external funding, either from industry or from elsewhere.

\section{Patients}

Those assessed were all new patients presenting to interventional pain management and were evaluated by one physician. There was no specific pattern followed to decide which patients were to be seen by any of the clinic's physicians. All patients aged 18 years and older were evaluated with a history, physical examination, psychological evaluation, review of records, and urine drug testing. These evaluations are a normal component of the comprehensive evaluation provided to patients at this clinic. No incentive, financial or otherwise, was provided to patients.

While all patients were given an explanation of the initial evaluation and the information collection process. Assessment by drug monitoring programs and urine drug testing is mandatory at this organization. Informed consent was obtained from all patients prior to assessment. Appropriate precautions were taken to protect the privacy and anonymity of all patients included in the study.

Inclusion criteria were that patients be over 18 years of age had been referred to a pain management center with at least a one-year duration of spinal pain. In addition, patients were willing to undergo the appropriate assessment and were also able to provide voluntary return informed consent for the evaluation. Exclusion criteria included an inability to understand the process, pain of less than a one-year duration, nonspinal pain, and patients unwilling to participate in the evaluation process.

A complete history was obtained from patients in reference to the duration of psychotherapeutic drug therapy, as well as the nature of the psychotherapeutic drugs, dosage, and duration. A drug profile history was assessed from the history, drug monitoring program reports and previous medical records.

Rapid drug screening was performed on all patients evaluated. Rapid drug screening is a one-step, lateral flow immunoassay for the simultaneous detection of up to 8 drugs by urine analysis.

A positive drug screen for an illicit drug was considered as illicit drug use. Any test result where the rapid drug screen did not correlate with patient history was sent for confirmation to the lab with liquid chromatography-tandem mass spectrometry (LC/MS/ MS). This drug testing process has been described in the past $(90,91)$.

The American Psychiatric Association's DSM-IV criteria were utilized for the assessment of major depression, generalized anxiety disorder, and somatization disorder. Other psychologically confirmed diagnoses were also included, and are reported herewith if they constituted more than $5 \%$ of the population.

Opioid intake was evaluated based on the dosage frequency and schedule of the drug, with conversion to morphine equivalents $(92,93)$.

Long-term opioid therapy was defined by opioid use episodes lasting longer than 90 days with at least 10 prescriptions (92). Any opioid therapy for less than 90 days or for postoperative pain or other indications were considered as acute opioid therapy. Long-term episodes were considered a higher dose if the average daily dose was $41 \mathrm{mg}$ morphine equivalence or greater, whereas episodes of $40 \mathrm{mg}$ of morphine equivalence or lower were considered as a lower dose.

The average daily dose is the total morphine equivalence for an episode divided by the episode's duration in days.

\section{Statistical Methods}

In this manuscript we present data on the most 
frequently prescribed types of opioids, as well as the percentage of patients receiving opioids alone and in combinations. Also analyzed were the maximum number of opioids utilized, the number of years on opioids, total opioid intake based on morphine equivalency in grams, daily average dose, and data related to doctor shopping and illicit drug use.

Differences were tested using the chi-squared test. Results were considered statistically significant if the $P$ value was less than 0.05 . The prevalence and $95 \%$ confidence intervals were calculated.

\section{Results}

\section{Participant Flow}

From January 2008 through November 2012, 1,350 patients who met the inclusion criterion of over the age of 18 with chronic spinal pain lasting at least one year were included and given a comprehensive evaluation by one physician.

\section{Demographic Characteristics}

Table 1 shows the demographic characteristics of the 1,350 consecutive patients assessed. There was sig-

Table 1. Demographics characteristics.

\begin{tabular}{|c|c|c|c|c|}
\hline & & "Men & Women & Total \\
\hline \multicolumn{2}{|l|}{$\%$ (Number) } & $41.0 \%(554)$ & $59.0 \%(796)$ & 1350 \\
\hline \multirow{3}{*}{ Age (years) } & Mean \pm SD & $47.4 \pm 14.3$ & $46.7 \pm 14.3$ & $47.0 \pm 14.3$ \\
\hline & $<65$ & $88.1 \%(288)$ & $89.1 \%(709)$ & \multirow{2}{*}{0.575} \\
\hline & $\geq 65$ & $11.9 \%(66)$ & $10.9 \%(87)$ & \\
\hline Height & Mean \pm SD & $70.2 \pm 3.2$ & $64.4^{*} \pm 2.8$ & $66.8 \pm 4.1$ \\
\hline Weight & Mean \pm SD & $204.2 \pm 47.3$ & $176.9^{*} \pm 49.2$ & $188.1 \pm 50.3$ \\
\hline Body Mass Index & Mean \pm SD & $29.1 \pm 6.4$ & $29.9^{*} \pm 7.8$ & $29.6 \pm 7.3$ \\
\hline \multirow{4}{*}{ Body Mass Index Distribution } & Underweight & $0.9 \%(5)$ & $2.8 \%(22)$ & $2.0 \%(27)$ \\
\hline & Normal weight & $24.9 \%(138)$ & $27.3 \%(217)$ & $26.3 \%(355)$ \\
\hline & Overweight & $37.0 \%(205)$ & $27.4 \%(218)$ & $31.3 \%(423)$ \\
\hline & Obesity & $37.2 \%(206)$ & $42.6 \% *(339)$ & $40.4 \%(545)$ \\
\hline \multirow{2}{*}{ Race } & White & $92.6 \%(513)$ & $93.0 \%(741)$ & $93.0 \%(1254)$ \\
\hline & African American and Others & $7.4 \%(41)$ & $7.0 \%(55)$ & $7.0 \%(96)$ \\
\hline \multirow{2}{*}{ Referral } & $\mathrm{MD}$ & $83.2 \%(461)$ & $88.3 \% *(703)$ & $86.2(1164)$ \\
\hline & Self & $16.8 \%(93)$ & $11.7 \%(93)$ & $13.8 \%(186)$ \\
\hline \multirow{3}{*}{ Smoking } & No & $31.4 \%(174)$ & $36.1 \%(287)$ & $34.1 \%(461)$ \\
\hline & Past & $8.8 \%(49)$ & $6.2 \%(49)$ & $7.3 \%(98)$ \\
\hline & Presently & $59.7 \%(331)$ & $57.8 \%(460)$ & $58.6 \%(791)$ \\
\hline \multicolumn{2}{|l|}{ Any Psychological Disorder } & $57.9 \%(321)$ & $75.0 \% *(598)$ & $68.0 \%(919)$ \\
\hline \multicolumn{2}{|l|}{ Major Depression } & $45.5 \%(252)$ & $66.2 \% *(527)$ & $57.7 \%(779)$ \\
\hline \multicolumn{2}{|l|}{ Generalized Anxiety Disorder } & $50.4 \%(279)$ & $63.3 \% *(504)$ & $58.0 \%(783)$ \\
\hline \multicolumn{2}{|l|}{ Somatization } & $5.1 \%(28)$ & $10.6 \% *(84)$ & $8.3 \%(112)$ \\
\hline \multicolumn{2}{|l|}{ Panic Disorder } & $8.3 \%(46)$ & $16.9 \% *(135)$ & $13.4 \%(181)$ \\
\hline \multicolumn{2}{|l|}{ Bipolar Disorder } & $3.4 \%(19)$ & $8.2 \% *(65)$ & $6.2 \%(84)$ \\
\hline \multicolumn{5}{|l|}{ Number of Regions Involved } \\
\hline \multicolumn{2}{|l|}{ One Region } & $44.8 \%(248)$ & $33.3 \% *(265)$ & $38.0 \%(513)$ \\
\hline \multicolumn{2}{|l|}{2 Regions } & $36.8 \%(204)$ & $36.2 \%(288)$ & $36.4 \%(492)$ \\
\hline \multicolumn{2}{|l|}{3 Regions } & $18.4 \%(102)$ & $30.5 \% *(243)$ & $25.6 \%(345)$ \\
\hline \multicolumn{2}{|l|}{ Lumbar } & $88.0 \%(487)$ & $89.0 \%(712)$ & $89.0 \%(1199)$ \\
\hline \multicolumn{2}{|l|}{ Cervical } & $54.0 \%(301)$ & $67.0 \% *(534)$ & $62.0 \%(835)$ \\
\hline \multicolumn{2}{|l|}{ Thoracic } & $26.0 \%(143)$ & $37.0 \% *(298)$ & $33.0 \%(441)$ \\
\hline \multicolumn{2}{|l|}{ Other } & $6.0 \%(33)$ & $3.4^{*} \%(27)$ & $4.4 \%(60)$ \\
\hline
\end{tabular}

* Significantly differ with men. 
nificant difference in the ratio of men to women $(41 \%$ versus $59 \%$ ). There were no differences in the age groups. Men as expected, were taller and heavier, however body mass index was higher in women than men. Only $2 \%$ of the patients were underweight; and $26.3 \%$ were of normal weight. The percentage of overweight patients was $31.3 \%$ while those considered obese were $40.4 \%$ for a total of over $70 \%$ in the overweight and obese category. Overall, $86.2 \%$ of patients were referred by another health care provider. Of these, a significantly higher percentage, $88.3 \%$ women versus $83.2 \%$ men, were referred by health care providers.

Patients who smoked at the time of evaluation was $58.6 \%$, with no significant differences in men and women. Past smoking was reported in $7.3 \%$ of the patients; $34.1 \%$ were nonsmokers.

At least one of the psychological disorders was present in $68 \%$ of the patients. Major depression and generalized anxiety disorder were present in almost $58 \%$ of the patients, with women constituting a higher proportion than men. Somatization was also higher in women with $10.6 \%$ versus $5.1 \%$ in men, with an overall prevalence of $8.3 \%$. Panic disorder and bipolar disorder were also higher in women with an overall prevalence of $13.4 \%$ for panic disorder and $6.2 \%$ for bipolar disorder.

The pain characteristics showed the majority of the patients with involvement of the lumbar region $(89 \%)$, followed by cervical $(62 \%)$, thoracic $(33 \%)$, and other regions (4.4\%). In addition, only one region was involved in $38 \%$ of patients, whereas 2 regions were involved in $36.4 \%$ of patients, and 3 regions were involved in $25.6 \%$ of patients.

\section{Psychotherapeutic Drug Use}

Table 2 illustrates psychotherapeutic drug use with opioids, benzodiazepines, carisoprodol, and various combinations. Ninety-four percent of patients were on opioids, $35 \%$ were on benzodiazepines, and $9.2 \%$ on carisoprodol. In reference to the combinations, 55.8 were taking only opioids, $29.3 \%$ were taking a combination of opioids and benzodiazepines, $4 \%$ were taking opioids and carisoprodol, and 5\% were taking a combination of all 3 drugs.

Table 3 shows the number of opioids taken during the course of treatment. As shown in Table 3, only $6.1 \%$ of the patients were not on chronic opioid therapy. The majority (55.7\%) were administered only one opioid, whereas $24.7 \%$ were administered 2 opioids, $8.8 \%$ were administered 3 opioids, and $4.7 \%$ were administered 4 or more opioids over the course of treatment.

Table 4 illustrates the number of years on opioids. The majority of patients were on opioids for greater than one year. Only $23.3 \%$ of patients were on chronic opioid therapy for less than one year. At least $35 \%$ of patients were on opioids for more than 5 years.

Table 2. Illustration of psychotherapeutic drugs use with opioids, benzodiazepines, carisoprodol, and various combinations.

\begin{tabular}{|l|c|c|c|}
\hline & Men & Women & Total \\
\hline None & $4.2 \%(23)$ & $5.8 \%(46)$ & $5.1 \%(69)$ \\
\hline Opioids & $95.3 \%(528)$ & $93.2 \%(742)$ & $94.0 \%(1270)$ \\
\hline Benzodiazepines & $29.2 \%(162)$ & $38.9 \%^{*}(310)$ & $35.0 \%(472)$ \\
\hline Carisoprodol & $7.2 \%(40)$ & $10.6 \%(84)$ & $9.2 \%(124)$ \\
\hline COMBINATIONS & \multicolumn{3}{|c|}{} \\
\hline Opioids & $63.0 \%(349)$ & $50.8 \%^{*}(404)$ & $55.8 \%(753)$ \\
\hline Benzodiazepines & $0.7 \%(4)$ & $0.6 \%(5)$ & $0.7 \%(9)$ \\
\hline Carisoprodol & $0.0 \%(0)$ & $0.3 \%(2)$ & $0.1 \%(2)$ \\
\hline Opioids \& Benzodiazepines & $24.9 \%(138)$ & $32.3 \%^{*}(257)$ & $29.3 \%(395)$ \\
\hline Opioids \& Carisoprodol & $3.6 \%(20)$ & $4.3 \%(34)$ & $4.0 \%(54)$ \\
\hline Opioids, Benzodiazepines \& Carisoprodol & $3.6 \%(20)$ & $6.0 \%(48)$ & $5.0 \%(68)$ \\
\hline Total & 554 & 796 & 1350 \\
\hline
\end{tabular}

* Significantly differ with men. 
Pain Physician: January/February 2013; 16:E1-E13

Table 3. Exposure to total number of opioids during course of treatments.

\begin{tabular}{|c|c|c|c|}
\hline $\begin{array}{l}\text { Number of } \\
\text { opioids }\end{array}$ & Frequency & Percent & $\begin{array}{c}\text { Cumulative } \\
\text { Percent } \\
\end{array}$ \\
\hline None & 83 & 6.1 & 6.1 \\
\hline 1 & 752 & 55.7 & 61.8 \\
\hline 2 & 333 & 24.7 & 86.5 \\
\hline 3 & 119 & 8.8 & 95.3 \\
\hline$\geq 4$ & 63 & 4.7 & 100.0 \\
\hline Total & 1350 & 100.0 & \\
\hline
\end{tabular}

Table 4. Number of years on opioids.

\begin{tabular}{|l|c|c|c|}
\hline Years & Frequency & Percent & Cumulative Percent \\
\hline$<1$ & 295 & 23.3 & 23.3 \\
\hline $1-2$ & 173 & 13.7 & 36.9 \\
\hline $2-5$ & 355 & 28.0 & 65.0 \\
\hline $5-10$ & 242 & 19.1 & 84.1 \\
\hline $10-15$ & 109 & 8.6 & 92.7 \\
\hline$>15$ & 93 & 7.3 & 100.0 \\
\hline Total & 1267 & 100.0 & \\
\hline
\end{tabular}

Table 5 illustrates the total dosage or intake of opioids in grams of morphine equivalents. The majority of the patients used more than 10 grams of opioids in their lifetime with over $20 \%$ using greater than 200 grams of opioid during the course of treatment. The mean morphine equivalent dosage of opioids per patient was $164 \pm$ 388.2 grams. This translates into $164,000 \mathrm{mgs}$ of morphine equivalents per patient during the course of treatment.

Table 6 shows the daily average dose, with $51.2 \%$ of patients taking $40 \mathrm{mg}$ or less per day of morphine equivalents. Over $28 \%$ of patients, however, were taking opioid dosages greater than $100 \mathrm{mg}$.

The most commonly used drug was hydrocodone ( $86 \%$ ) followed by oxycodone (28\%) (Table 7$)$. Tramadol was used in only $10 \%$ of patients. Codeine was used in a small proportion of patients, 46 out of 1,350. Methadone was used in $5.6 \%$. The most commonly used benzodiazepine was alprazolam, which was used in 263 patients, followed by diazepam and others.

Table 5. Total intake opioids (morphine equivalents dose) in grams.

\begin{tabular}{|l|c|c|c|c|}
\hline Grams & Frequency & Percent & Cumulative \% & Mean \pm SD \\
\hline$<10$ & 241 & 19.0 & 19.0 & $4.0 \pm 2.7$ \\
\hline $10-40$ & 338 & 26.7 & 45.7 & $22.0 \pm 8.0$ \\
\hline $41-100$ & 234 & 18.5 & 64.2 & $67.0 \pm 17.1$ \\
\hline $101-200$ & 191 & 15.1 & 79.2 & $144.0 \pm 29.0$ \\
\hline $201-300$ & 95 & 7.5 & 86.7 & $240.0 \pm 26.3$ \\
\hline $301-500$ & 78 & 6.2 & 92.9 & $383.0 \pm 53.3$ \\
\hline$\geq 501$ & 90 & 7.1 & 100.0 & $1147.0 \pm 969.7$ \\
\hline Total & 1267 & 100.0 & & $164.0 \pm 388.2$ \\
\hline
\end{tabular}

Table 6. Daily average dose.

\begin{tabular}{|c|c|c|c|c||}
\hline Mg per Day & Frequency & Percent & Cumulative $\%$ & Mean \pm SD(mg) \\
\hline$\leq 20$ & 121 & 9.6 & 9.6 & $16.0 \pm 4.3$ \\
\hline $21-30$ & 287 & 22.8 & 32.4 & $28.0 \pm 3.5$ \\
\hline $31-40$ & 237 & 18.8 & 51.2 & $40.0 \pm .08$ \\
\hline $41-50$ & 74 & 5.9 & 57.1 & $60.0 \pm 1.9$ \\
\hline $51-60$ & 62 & 4.9 & 62.0 & $69.0 \pm 2.4$ \\
\hline $61-70$ & 30 & 2.4 & 64.4 & $80.0 \pm 1.6$ \\
\hline $71-80$ & 54 & 4.3 & 68.7 & $88.0 \pm 2.8$ \\
\hline $81-90$ & 14 & 1.1 & 69.8 & $100.0 \pm 1.1$ \\
\hline $91-100$ & 23 & 1.8 & 71.6 & $152.0 \pm 30.7$ \\
\hline $101-200$ & 154 & 12.2 & 83.9 & $247.0 \pm 26.1$ \\
\hline $201-300$ & 125 & 9.9 & 93.8 & $446.0 \pm 146.1$ \\
\hline$>301$ & 78 & 6.2 & 100.0 & $100.0 \pm 119.4$ \\
\hline
\end{tabular}

Average daily intake of opioids $100 \mathrm{mg}$ (morphine equivalents) 


\section{Psychotherapeutic Drug Abuse and Illicit Drug Use}

Past and present drug abuse and illicit drug use patterns are shown in Table 8 . Based on the available history, $1.1 \%$ of the patients were engaged in doctor shopping, whereas $45.7 \%$ had used illicit drugs in the past. The majority (601 patients) used marijuana followed by cocaine (99 patients) and methamphetamine (46 patients). Marijuana use was significantly higher in men than women $(52.7 \%$ versus $38.8 \%)$.

With reference to current drug use (within 30 days), $1.3 \%$ of patients tested positive for prescription drug abuse by urine drug testing, however, $7.9 \%$ of patients tested positive for illicit drug use. Among these 106 patients, 99 tested positive for marijuana, 7 tested positive for cocaine, and only one was confirmed positive for methamphetamine.

\section{Discussion}

This prospective evaluation of the demographic characteristics, drug usage, and illicit drug use patterns of patients presenting to an interventional pain management practice who had chronic pain of at least one year and who had undergone a minimum of 3 months of opioid therapy, illustrates that a total of $45.7 \%$ of them had a history of past illicit drug use, including $7.9 \%$ who had used illicit drugs at the time of the evaluation and $1.3 \%$ who were abusing prescription drugs. Marijuana was the most common drug used in the past and also at the time of assessment.

This prospective evaluation of 1,350 patients shows that a large percentage of patients, almost $94 \%$, were taking opioids, $35 \%$ were taking benzo- diazepines, over $9 \%$ were taking carisoprodol, and over $29 \%$ were taking opioids in combination with benzodiazepines. In addition, a significant percentage $(40.8 \%)$ had received over $40 \mathrm{mg}$ of morphine equivalent doses of opioids over a long period of time (with $35 \%$ for longer than 5 years). There was a total dose of $164,000 \mathrm{mg}$ morphine equivalents per patient over the course of treatment. More men were receiving only opioids compared to women. Furthermore, women were receiving benzodiazepines and combinations of opioids and benzodiazepines. Overall, there was no difference in patients receiving opi-

Table 7. Frequency of prescribed opioids and benzodiazepines.

\begin{tabular}{|l|c|c|}
\hline \multicolumn{1}{|c|}{ Medication } & Count & Percent \\
\hline Hydrocodone & 1165 & $86.3 \%$ \\
\hline Oxycodone & 380 & $28.1 \%$ \\
Tramadol & 133 & $9.9 \%$ \\
\hline Morphine & 105 & $7.8 \%$ \\
\hline Methadone & 75 & $5.6 \%$ \\
\hline Codeine & 46 & $3.4 \%$ \\
\hline Transdermal Fentanyl & 40 & $3.0 \%$ \\
Hydromorphone & 19 & $1.4 \%$ \\
\hline Oxymorphone & 12 & $0.9 \%$ \\
Diazepam & 125 & $9.3 \%$ \\
\hline Alprazolam & 263 & $19.5 \%$ \\
\hline Lorazepam & 51 & $3.8 \%$ \\
Clonazepam & 87 & $6.4 \%$ \\
\hline Carisoprodol & 123 & $9.1 \%$ \\
\hline
\end{tabular}

Table 8. Drug abuse and illicit drug use patterns

\begin{tabular}{|c|c|c|c|c|}
\hline \multicolumn{5}{|l|}{ PAST } \\
\hline & & Men (554) & Women (796) & Total (1350) \\
\hline \multicolumn{2}{|l|}{ Doctor Shopping } & $1.6 \%(9)$ & $0.8 \%(6)$ & $1.1 \%(15)$ \\
\hline \multicolumn{2}{|l|}{ Past Illicit Drug Use } & $54.0 \%(299)$ & $39.8 \% *(317)$ & $45.7 \%(616)$ \\
\hline \multirow{3}{*}{ Past Illicit Drug Use } & Marijuana & $52.7 \%(292)$ & $38.8 \% *(309)$ & $44.5 \%(601)$ \\
\hline & Cocaine & $8.6 \%(48)$ & $6.4 \%(51)$ & $7.3 \%(99)$ \\
\hline & Methamphetamine & $4.1 \%(23)$ & $2.9 \%(23)$ & $3.4 \%(46)$ \\
\hline \multicolumn{5}{|l|}{ CURRENT } \\
\hline \multicolumn{2}{|l|}{ Prescription Abuse } & $2.2 \%(12)$ & $0.8 \% *(6)$ & $1.3 \%(18)$ \\
\hline \multicolumn{2}{|l|}{ Illicit Drug Use } & $9.4 \%(52)$ & $6.8 \%(54)$ & $7.9 \%(106)$ \\
\hline \multirow{3}{*}{ Illicit Drug Use } & Marijuana & 49 & 50 & $7.3 \%(99)$ \\
\hline & Cocaine & 5 & 4 & $0.5 \%(7)$ \\
\hline & Methamphetamine & 1 & & $0.07 \%(1)$ \\
\hline
\end{tabular}


oids based on gender, although the use of benzodiazepines was higher in women.

The results of this study are different from our previous evaluation (89), however, the previous evaluation included only 100 patients and the results showed $90 \%$ of them were taking opioids. This increased to $94 \%$ in this study. In contrast, the present assessment shows only $1.3 \%$ of the patients using nonprescribed psychotherapeutic agents. Illicit drug use was demonstrated in $7.9 \%$ of the patients compared to $23 \%$ in 2004 . In this study it clearly shows that prior to presenting to pain management clinics, patients have tried multiple drugs, frequently in high doses. Their high use of opioids came from primary care providers rather than from pain clinics.

The epidemic of opioid abuse, overuse, and abuse continues despite multiple guidelines and regulations. In fact, the majority of fatalities (60\%) reported (81) are related to prescription opioid use. These fatalities can be in patients taking small doses as well as high doses even though they are more common in patients taking high doses. Nevertheless, it has been shown that small doses are also responsible for significant fatalities (33,81,94-99). In addition, increased opioid sales have been attributed proportionately to treatment admissions and deaths (81).

Thus, interventional pain management physicians are faced with $94 \%$ of patients having been exposed to opioids and approximately $30 \%$ to a combination of opioids with other controlled substances. There has been a shift toward an increased reliance on opioids for treating chronic pain with or without other treatment (31-33).

The dramatic increases in the number of opioid prescriptions for noncancer pain over the past 2 decades coincides with the liberalization of laws governing opioid prescribing for the treatment of chronic noncancer pain by the state medical boards in the late 1990s. Other contributing factors include the introduction of new pain management standards for inpatient and outpatient medical care issued by the Joint Commission on Accreditation of Health Care Organizations (JCAHO) in 2000; multiple physicians and organizations advocating the increased use of opioids in the treatment of chronic noncancer pain; aggressive marketing by the pharmaceutical industry; the development of long-acting opioids; a growing awareness of the right to pain relief empowered by JCAHO standards; and with a media that sensationalizes anecdotal patient experiences by highlighting "heroic" physicians who have been victimized because of their heavy opioid prescribing patterns (31).

While proponents continue to advocate increased opioid therapy, responsible opioid prescribers and opponents have been conducting a postmortem analysis of the opioid epidemic and its consequences (31). Most agree that there have been gross miscalculations and misinformation behind providing therapy on such a wide scale in the absence of evidence and proven safety. In fact, Russell Portenoy, the author of the studies that falsely promoted effectiveness and safety has recently admitted to the devastating effects of opioid abuse and to the widespread miscalculation and misinformation that has led to such devastating abuse patterns (100).

Among all the illicit drugs used in the United States, marijuana has been the illicit substance most commonly used for several decades (80). However, in recent years, the medicalization of marijuana has increased and 2 states have approved it for recreational use (http://apps.leg.wa.gov/RCW/default. aspx?cite $=69.51$ A\&full=true). Proponents argue that it is a plant that is highly effective for various types of ailments and that the side effects are minimal or nonexistent. Consequently, marijuana is being decriminalized. However, marijuana use is associated with impaired educational attainment, reduced workplace productivity, and an increased risk for abuse of other substances. Marijuana use has been shown to play a major role in motor vehicle crashes and to cause adverse effects on cardiovascular and respiratory systems. The use of marijuana or hashish produces feelings of relaxation and well-being and impairs cognitive function and the performance of psychomotor tasks (89). Associations between early cannabis use and later drug use and abuse/dependence have been demonstrated, and may arise from the effects of the peer and social context within which cannabis is used and obtained (89). At least one-third of the US population has used marijuana sometime in their lives. The drug is considered a "gateway" to the world of illicit drug abuse. Various reasons attributed to its widespread use are: relaxed public perception of the harm; popularization by the media and by groups advocating legalization; the Internet; and the trend of smoking marijuana-filled cigars. In this study, current marijuana use was identified in $7.3 \%$ of patients, which is similar to $7.0 \%$ in the general population (80), even though lifetime exposure was lower in present patient population ( $44.5 \%$ versus $47.1 \%$ ). 
Our results are similar to the other published results (101). Zvolensky et al (101), in a representative sample of US adults examined the connections between chronic pain and marijuana after controlling for sociodemographic variables, lifetime history of depression, and alcohol abuse/dependence. Current chronic pain was significantly associated with lifetime marijuana use; however, there was no significant association between current chronic pain and current marijuana use, similar to the results of our study.

Cocaine and methamphetamine were detected in a very small percentage of patients: $0.5 \%$ for cocaine and $0.07 \%$ for methamphetamine. Based on NSDUH survey, however, lifetime exposure of cocaine was present in $7.3 \%$ of patients and methamphetamine in $3.4 \%$ of patients compared to $14.7 \%$ and $5.1 \%$, in the general population (80).

This is the largest study assessing opioid exposure prior to presenting to interventional pain management settings in the United States. It is a prospective evaluation with assessment from various sources. It may be criticized for utilizing rapid drug screening instead of LC/MS/MS, or enzyme immunoassay. This issue has been debated. Some assert that each and every specimen must be sent to a lab and confirmed for a myriad of drugs; others state that immunoassay testing is reliable and that confirmation should only be requested if there are questions regarding results and patient history $(32,90,91)$. There is a significant correlation between immunoassay and chromatography for the majority of drugs in pain medicine settings $(90,91)$. However, on occasion, it should also be noted that even confirmatory testing requires expert assistance for interpretation (32). In this study we have taken appropriate caution to send all questionable specimens for confirmation.

Despite many advantages and the size of the assessment, this study may be criticized. Limitations include that patients were assessed by only one physician, it was conducted in a single interventional pain management setting in the United States, rapid drug screen testing was used, and to some extent there was a reliance on patient history. All of the disadvantages have been discussed above and the study is considered comprehensive, illustrating that the majority of patients initially receive their medications from primary care physicians.

\section{Conclusion}

The results of this evaluation show that $94 \%$ of patients are on long-term opioids prior to presenting to interventional pain management, which were initiated and maintained by primary care physicians, in rather high doses and on a long-term basis. Illicit drug use also is common even though it is declining significantly. A large percentage of individuals have used illicit drugs in the past, however, current illicit drug use is present in only $7.9 \%$ of patients, which is similar to its use in the general population.

\section{Acknowledgments}

The authors wish to thank Sekar Edem for assistance in the search of the literature, Tom Prigge, MA, Alvaro F. Gómez, MA, and Laurie Swick, BS for manuscript review, and Tonie M. Hatton and Diane E. Neihoff, transcriptionists, for their assistance in preparation of this manuscript. We would like to thank the editorial board of Pain Physician for review and criticism in improving the manuscript.

\section{References}

1. Institute of Medicine (IOM). Relieving Pain in America: A Blueprint for Transforming Prevention, Care, Education, and Research. The National Academies Press, Washington, DC, June 29, 2011

2. Manchikanti L, Singh V, Falco FJE, Benyamin RM, Hirsch JA. Epidemiology of low back pain in adults. Neuromodulation 2012; in press.

3. Harkness EF, Macfarlane GJ, Silman AJ, McBeth J. Is musculoskeletal pain more common now than 40 years ago?: Two population-based cross-sectional stud- ies. Rheumatology (Oxford) 2005; 44:890895 .

4. Freburger JK, Holmes GM, Agans RP, Jackman AM, Darter JD, Wallace AS, Castel LD, Kalsbeek WD, Carey TS. The rising prevalence of chronic low back pain. Arch Intern Med 2009; 169:251-258.

5. Hoy DG, Bain C, Williams G, March L, Brooks P, Blyth F, Woolf A, Vos T, Buchbinder R. A systematic review of the global prevalence of low back pain. Arthritis Rheum 2012; 64:2028-2037.

6. Hoy DG, Protani M, De R, Buchbinder
R. The epidemiology of neck pain. Best Pract Res Clin Rheumatol 2010; 24:783792.

7. Dunning KK, Davis KG, Cook C, Kotowski SE, Hamrick C, Jewell G, Lockey J. Costs by industry and diagnosis among musculoskeletal claims in a state workers compensation system: 1999-2004. Am J Ind Med 2010; 53:276284 .

8. Deyo RA, Mirza SK, Turner JA, Martin BI. Overtreating chronic back pain: Time to back off? J Am Board Fam Med 
2009; 22:62-68.

9. Gupta S, Gupta M, Nath S, Hess GM Survey of European pain medicine practice. Pain Physician 2012; 15:E983E994.

10. Manchikanti L, Falco FJE, Singh V, Pampati V, Parr AT, Benyamin RM, Fellows $B$, Hirsch JA. Utilization of interventional techniques in managing chronic pain in the Medicare population: Analysis of growth patterns from 2000 to 2011. Pain Physician 2012; 15:E969-E982.

11. Manchikanti L, Benyamin RM, Swicegood JR, Falco FJE, Datta S, Pampati V, Fellows B, Hirsch JA. Assessment of practice patterns of perioperative management of antiplatelet and anticoagulant therapy in interventional pain management. Pain Physician 2012; 15:E955-E968.

12. Martin BI, Mirza SK, Flum DR, Wickizer TM, Heagerty PJ, Lenkoski AF, Deyo RA. Repeat surgery after lumbar decompression for herniated disc: The quality implications of hospital and surgeon variation. Spine J 2012; 12:8997.

13. Rajaee SS, Bae HW, Kanim LE, Delamarter RB. Spinal fusion in the United States: Analysis of trends from 1998 to 2008. Spine (Phila Pa 1976) 2012; 37:67-76.

14. Hollingworth W, Turner JA, Welton NJ, Comstock BA, Deyo RA. Costs and cost-effectiveness of spinal cord stimulation (SCS) for failed back surgery syndrome: An observational study in a workers' compensation population. Spine (Phila Pa 1976) 2011; 36:2076-2083.

15. Deyo RA, Martin BI, Kreuter W, Jarvik JG, Angier H, Mirza SK. Revision surgery following operations for lumbar stenosis. J Bone Joint Surg Am 2011; 93:1979-1986.

16. Manchikanti L, Singh V, Caraway DL, Benyamin RM, Falco FJE, Hirsch JA. Proposed physician payment schedule for 2013: Guarded prognosis for interventional pain management. Pain Physician 2012; 15:E615-E627.

17. Manchikanti L, Hirsch JA. Obamacare 2012: Prognosis unclear for interventional pain management. Pain Physician 2012; 15:E629-E640.

18. Manchikanti L, Caraway DL, Falco FJE, Benyamin RM, Hansen $\mathrm{H}$, Hirsch JA. CMS proposal for interventional pain management by nurse anesthetists: Evidence by proclamation with poor prognosis. Pain Physician 2012; 15:E641-
E664.

19. Singh V, Manchikanti L, Onyewu O, Benyamin RM, Datta S, Geffert S, Parr AT, Falco FJE. An update of appraisal of accuracy of thoracic discography as a diagnostic test for chronic spinal pain. Pain Physician 2012; 15:E757-E776.

20. Onyewu O, Manchikanti L, Falco FJE, Singh V, Geffert S, Helm II S, Cohen SP, Hirsch JA. An update of the appraisal of the accuracy and utility of cervical discography in chronic neck pain. Pain Physician 2012; 15:E777-E806.

21. Falco FJE, Datta S, Manchikanti L, Sehgal N, Geffert S, Singh V, Smith HS, Boswell MV. An updated review of diagnostic utility of cervical facet joint injections. Pain Physician 2012; 15:E807$\mathrm{E} 838$.

22. Falco FJE, Manchikanti L, Datta S, Wargo BW, Geffert S, Bryce DA, Atluri S, Singh V, Benyamin RM, Sehgal N, Ward S, Helm II S, Gupta S, Boswell MV. Systematic review of therapeutic effectiveness of cervical facet joint interventions: An update. Pain Physician 2012; 15:E839-E868.

23. Falco FJE, Manchikanti L, Datta S, Sehgal N, Geffert S, Onyewu O, Singh V, Bryce DA, Benyamin RM, Simopoulos TT, Vallejo R, Gupta S, Ward SP, Hirsch JA. An update of the systematic assessment of the diagnostic accuracy of lumbar facet joint nerve blocks. Pain Physician 2012; 15:E869-E907.

24. Falco FJE, Manchikanti L, Datta S, Sehgal N, Geffert S, Onyewu O, Zhu J, Coubarous S, Hameed M, Ward SP, Sharma $M$, Hameed $H$, Singh V, Boswell MV. An update of the effectiveness of therapeutic lumbar facet joint interventions. Pain Physician 2012; 15:E909-E953.

25. Benyamin RM, Manchikanti L, Parr AT, Diwan SA, Singh V, Falco FJE, Datta S, Abdi S, Hirsch JA. The effectiveness of lumbar interlaminar epidural injections in managing chronic low back and lower extremity pain. Pain Physician 2012; 15: E363-E404.

26. Diwan SA, Manchikanti L, Benyamin RM, Bryce DA, Geffert S, Hameed H, Sharma ML, Abdi S, Falco FJE. Effectiveness of cervical epidural injections in the management of chronic neck and upper extremity pain. Pain Physician 2012; 15:E405-E434.

27. Helm S II, Benyamin RM, Chopra P, Deer TR, Justiz R. Percutaneous adhesiolysis in the management of chronic low back pain in post lumbar sur- gery syndrome and spinal stenosis: A systematic review. Pain Physician 2012; 15: $\mathrm{E}_{435}-\mathrm{E}_{4} 62$.

28. Manchikanti KN, Atluri S, Singh V, Geffert S, Sehgal N, Falco FJE. An update of evaluation of therapeutic thoracic facet joint interventions. Pain Physician 2012; 15: $E_{463}-E_{481 .}$

29. Atluri S, Singh V, Datta S, Geffert S, Sehgal N, Falco FJE. Diagnostic accuracy of thoracic facet joint nerve blocks: An update of the assessment of evidence. Pain Physician 2012; 15:E483-E496.

30. Benyamin RM, Wang VC, Vallejo R, Singh V, Helm S II. A systematic evaluation of thoracic interlaminar epidural injections. Pain Physician 2012; 15:E497E514.

31. Manchikanti L, Abdi S, Atluri S, Balog CC, Benyamin RM, Boswell MV, Brown $K R$, Bruel BM, Bryce DA, Burks PA, Burton AW, Calodney AK, Caraway DL, Cash KA, Christo PJ, Damron KS, Datta S, Deer TR, Diwan S, Eriator I, Falco FJE, Fellows F, Geffert S, Gharibo CG, Glaser SE, Grider JS, Hameed H, Hameed $M$, Hansen $H$, Harned ME, Hayek SM, Helm II S, Hirsch JA, Janata JW, Kaye $A D$, Kaye AM, Kloth DS, Koyyalagunta D, Lee M, Malla Y, Manchikanti KN, McManus CD, Pampati V, Parr AT, Pasupuleti R, Patel VB, Sehgal N, Silverman SM, Singh V, Smith HS, Snook LT, Solanki DR, Tracy DH, Vallejo R, Wargo BW. American Society of Interventional Pain Physicians (ASIPP) guidelines for responsible opioid prescribing in chronic non-cancer pain: Part I - Evidence assessment. Pain Physician 2012; 15:S1-S66.

32. Manchikanti L, Abdi S, Atluri S, Balog CC, Benyamin RM, Boswell MV, Brown KR, Bruel BM, Bryce DA, Burks PA, Burton AW, Calodney AK, Caraway DL, Cash KA, Christo PJ, Damron KS, Datta S, Deer TR, Diwan S, Eriator I, Falco FJE, Fellows F, Geffert S, Gharibo CG, Glaser SE, Grider JS, Hameed H, Hameed $M$, Hansen $H$, Harned ME, Hayek SM, Helm II S, Hirsch JA, Janata JW, Kaye $A D$, Kaye AM, Kloth DS, Koyyalagunta D, Lee M, Malla Y, Manchikanti KN, McManus CD, Pampati V, Parr AT, Pasupuleti R, Patel VB, Sehgal N, Silverman SM, Singh V, Smith HS, Snook LT, Solanki DR, Tracy DH, Vallejo R, Wargo BW. American Society of Interventional Pain Physicians (ASIPP) guidelines for responsible opioid prescribing in chronic non-cancer pain: Part 2 
- Guidance. Pain Physician 2012; 15:S67S116.

33. Manchikanti L, Helm II S, Fellows B, Janata JW, Pampati V, Grider JS, Boswell MV. Opioid epidemic in the United States. Pain Physician 2012; 15:ES9$\mathrm{ES}_{3} 8$.

34. Koyyalagunta $D$, Bruera E, Solanki DR, Nouri KH, Burton AW, Toro MP, Bruel BM, Manchikanti L. A systematic review of randomized trials on the effectiveness of opioids for cancer pain. Pain Physician 2012; 15:ES39-ES58.

35. Sehgal N, Manchikanti L, Smith HS Prescription opioid abuse in chronic pain: A review of opioid abuse predictors and strategies to curb opioid abuse. Pain Physician 2012; 15:ES67ES92.

36. Manchikanti L, Singh V, Caraway DL, Benyamin RM, Falco FJE, Hirsch JA Physician payment outlook for 2012: Déjà vu. Pain Physician 2012; 15:E27E52.

37. Magalhaes FN, Dotta L, Sasse A, Teixera MJ, Fonoff ET. Ozone therapy as a treatment for low back pain secondary to herniated disc: A systematic review and meta-analysis of randomized controlled trials. Pain Physician 2012; 15:E115-E129.

38. Manchikanti L, Singh V, Hirsch JA. Saga of payment systems of ambulatory surgery centers for interventional techniques: An update. Pain Physician 2012; 15:109-130.

39. Manchikanti L, Malla Y, Wargo BW, Cash KA, Pampati V, Fellows B. Complications of fluoroscopically directed facet joint nerve blocks: A prospective evaluation of 7,500 episodes with 43,000 nerve blocks. Pain Physician 2012; 15:E143-E150.

40. Manchikanti L, Malla Y, Wargo BW, Cash KA, Pampati V, Fellows B. A prospective evaluation of complications of 10,000 fluoroscopically directed epidural injections. Pain Physician 2012; 15:131-140.

41. Manchikanti L, Singh V, Caraway DL, Benyamin RM, Hirsch JA. Medicare physician payment systems: Impact of 2011 schedule on interventional pain management. Pain Physician 2011; 14: $E_{5}-E_{33}$.

42. Manchikanti L, Caraway DL, Parr AT, Fellows B, Hirsch JA. Patient Protection and Affordable Care Act of 2010: Re- forming health care reform for the new decade. Pain Physician 2011; 14:E35-E67.

43. Parr AT, Manchikanti L, Hameed $H$, Conn A, Manchikanti KN, Benyamin RM, Diwan S, Singh V, Abdi S. Caudal epidural injections in the management of chronic low back pain: A systematic appraisal of the literature. Pain Physician 2012; 15: E159-E198.

44. Manchikanti L, Buenaventura RM, Manchikanti KN, Ruan X, Gupta S, Smith HS, Christo PJ, Ward SP. Effectiveness of therapeutic lumbar transforaminal epidural steroid injections in managing lumbar spinal pain. Pain Physician 2012; 15:E199-E245.

45. Hansen H, Manchikanti L, Simopoulous TT, Christo PJ, Gupta S, Smith HS, Hameed $\mathrm{H}$, Cohen SP. A systematic evaluation of the therapeutic effectiveness of sacroiliac joint interventions. Pain Physician 2012; 15:E247-E278.

46. Helm S II, Deer TR, Manchikanti L, Datta S, Chopra P, Singh V, Hirsch JA. Effectiveness of thermal annular procedures in treating discogenic low back pain. Pain Physician 2012; 15:E279-E304.

47. Simopoulos TT, Manchikanti L, Singh V, Gupta S, Hameed H, Diwan S, Cohen SP. A systematic evaluation of prevalence and diagnostic accuracy of sacroiliac joint interventions. Pain Physician 2012; 15:E305-E344.

48. Pesce A, West C, Gonzales E, Rosenthal M, West R, Mikel C, Almazan P, Latyshev S, Horn P. Illicit drug use correlates with negative urine drug test results for prescribed hydrocodone, oxycodone, and morphine. Pain Physician 2012; 15:E687-E692.

49. De Maddalena C, Bellini M, Berra M, Meriggiola MC, Aloisi AM. Opioid-induced hypogonadism: Why and how to treat it. Pain Physician 2012; 15:ES111ES118.

50. Owen GT, Burton AW, Schade CM, Passik S. Urine drug testing: Current recommendations and best practices. Pain Physician 2012; 15:ES119-ES133.

51. Wang $H$, Fischer $C$, Chen $G$, Weinsheimer N, Gantz S, Schiltenwolf M. Does long-term opioid therapy reduce pain sensitivity of patients with chronic low back pain? Evidence from quantitative sensory testing. Pain Physician 2012; 15:ES135-ES143.

52. Smith HS, Elliott JA. Opioid-induced androgen deficiency (OPIAD). Pain Phy- sician 2012; 15:ES145-ES156.

53. Krashin DL, Merrill JO, Trescot AM. Opioids in the management of HIVrelated pain. Pain Physician 2012; 15:ES157-ES168.

54. Goodin A, Blumenschein K, Freeman PR, Talbert J. Consumer/patient encounters with prescription drug monitoring programs: Evidence from a Medicaid population. Pain Physician 2012; 15:ES169-ES175.

55. Atluri S, Akbik H, Sudarshan G. Prevention of opioid abuse in chronic noncancer pain: An algorithmic, evidence based approach. Pain Physician 2012; 15:ES177-ES189.

56. Fischer B, Argento E. Prescription opioid related misuse, harms, diversion and interventions in Canada: A review. Pain Physician 2012; 15:ES191-203.

57. Nijs J, Kosek E, Van Oosterwijck J, Meeus M. Dysfunctional endogenous analgesia during exercise in patients with chronic pain: To exercise or not to exercise? Pain Physician 2012; 15:ES205ES213.

58. Colson J, Helm S, Silverman SM. Office-based opioid dependence treatment. Pain Physician 2012; 15:ES231$\mathrm{ES}_{236}$

59. Manchikanti L, Ailinani H, Koyyalagunta D, Datta S, Singh V, Eriator I, Sehgal $\mathrm{N}$, Shah RV, Benyamin RM, Vallejo R, Fellows B, Christo PJ. A systematic review of randomized trials of long-term opioid management for chronic noncancer pain. Pain Physician 2011; 14:91121.

6o. Colson J, Koyyalagunta D, Falco FJE, Manchikanti L. A systematic review of observational studies on the effectiveness of opioid therapy for cancer pain. Pain Physician 2011; 14:E85-E102.

61. Manchikanti L, Singh V, Caraway DL, Benyamin RM. Breakthrough pain in chronic non-cancer pain: Fact, fiction, or abuse. Pain Physician 2011; 14:E103E117.

62. Christo PJ, Manchikanti L, Ruan X, Bottros $M$, Hansen $H$, Solanki D, Jordan $\mathrm{AE}$, Colson J. Urine drug testing in chronic pain. Pain Physician 2011; 14:123-143.

63. Solanki DR, Koyyalagunta D, Shah RV, Silverman SM, Manchikanti L. Monitoring opioid adherence in chronic pain patients: Assessment of risk of substance misuse. Pain Physician 2011; 14:E119-E131. 
64. Lee M, Silverman $\mathrm{SM}$, Hansen $\mathrm{H}, \mathrm{Pa}$ tel VB, Manchikanti L. A comprehensive review of opioid-induced hyperalgesia. Pain Physician 2011; 14:145-161.

65. Manchikanti L, Vallejo R, Manchikanti KN, Benyamin RM, Datta S, Christo PJ. Effectiveness of long-term opioid therapy for chronic non-cancer pain. Pain Physician 2011; 14:E133-E156.

66. Koyyalagunta D, Burton AW, Toro MP, Driver L, Novy DM. Opioid abuse in cancer pain: Report of two cases and presentation of an algorithm of multidisciplinary care. Pain Physician 2011; 14:E361-E371.

67. Gupta A, Patton C, Diskina D, Cheatle M. Retrospective review of physician opioid prescribing practices in patients with aberrant behaviors. Pain Physician 2011; 14:383-389.

68. Roxburgh A, Bruno R, Larance B, Burns L. Prescription of opioid analgesics and related harms in Australia. Med J Aust 2011; 195:280-284.

69. Baldini A, Von Korff M, Lin EH. A review of potential adverse effects of long-term opioid therapy: A practitioner's guide. Prim Care Companion CNS Disord 2012; 14.

70. Merrill JO, Von Korff M, Banta-Green C), Sullivan MD, Saunders KW, Campbell $\mathrm{Cl}$, Weisner $\mathrm{C}$. Prescribed opioid difficulties, depression and opioid dose among chronic opioid therapy patients. Gen Hosp Psychiatry 2012; 34:581-587.

71. Grattan A, Sullivan MD, Saunders KW, Campbell Cl, Von Korff MR. Depression and prescription opioid misuse among chronic opioid therapy recipients with no history of substance abuse. Ann Fam Med 2012; 10:304-311.

72. Howe CQ, Sullivan MD, Saunders KW, Merrill JO, Banta-Green CJ, Weisner C, Campbell $\mathrm{Cl}$, Von Korff M. Depression and ambivalence toward chronic opioid therapy for chronic noncancer pain. Clin J Pain 2012; 28:561-566.

73. Banta-Green CJ, Von Korff M, Sullivan MD, Merrill JO, Doyle SR, Saunders K. The prescribed opioids difficulties scale: A patient-centered assessment of problems and concerns. Clin J Pain 2010; 26:489-497.

74. Von Korff M, Merrill JO, Rutter CM, Sullivan M, Campbell $\mathrm{Cl}$, Weisner C. Time-scheduled vs. pain-contingent opioid dosing in chronic opioid therapy. Pain 2011; 152:1256-1262.

75. Von Korff M. Commentary on Boscarino et al: Understanding the spectrum of opioid abuse, misuse and harms among chronic opioid therapy patients. Addiction 2010; 105:1783-1784.

76. Von Korff M, Kolodny A, Deyo RA, Chou R. Long-term opioid therapy reconsidered. Ann Intern Med 2011; 155:325-328.

77. Deyo RA, Smith DH, Johnson ES, Donovan M, Tillotson CJ, Yang X, Petrik AF, Dobscha SK. Opioids for back pain patients: Primary care prescribing patterns and use of services. J Am Board Fam Med 2011; 24:717-727.

78. Morasco BJ, Duckart JP, Carr TP, Deyo RA, Dobscha SK. Clinical characteristics of veterans prescribed high doses of opioid medications for chronic noncancer pain. Pain 2010; 151:625-632.

79. Von Korff MR. Opioids for chronic noncancer pain: As the pendulum swings, who should set prescribing standards for primary care? Ann Fam Med 2012; 10:302-303.

8o. Substance Abuse and Mental Health Services Administration. Results from the 2010 National Survey on Drug Use and Health: Summary of National Findings. NSDUH Series H-41, HHS Publication No. (SMA) 11-4658. Substance Abuse and Mental Health Services Administration, Rockville, MD, 2011. www.samhsa.gov/data/ NSDUH/2k1oNSDUH/2k1oResults.pdf

81. Centers for Disease Control and Prevention. CDC grand rounds: Prescription drug overdoses - a U.S. epidemic. MMWR Morb Mortal Wkly Rep 2012; 61:10-13.

82. United States Department of Justice, Drug Enforcement Administration. Automation of Reports and Consolidated Orders System (ARCOS). Springfield, VA, 2011. www.deadiversion.usdoj.gov/ arcos/index.html.

83. Volkow ND, McLellan TA, Cotto JH. Characteristics of opioid prescriptions in 2009. JAMA 2011; 305:1299-1301.

84. Governale L. Outpatient prescription opioid utilization in the U.S., years 2000 - 2009. Drug Utilization Data Analysis Team Leader, Division of Epidemiology, Office of Surveillance and Epidemiology. Presentation for U.S. Food and Drug Administration, July 22, 2010.

www.fda.gov/downloads/AdvisoryCommittees/CommitteesMeetingMaterials/Drugs/AnestheticAndLifeSupportDrugsAdvisoryCommittee/ UCM220950.pdf

85. SDI, Vector One ${ }^{\circledR}$ : National.
86. IMS Institute for Healthcare Informatics. The use of medicines in the United States: Review of 2011. April 2012. www. imshealth.com/ims/Global/Content/ Insights/IMS\%2olnstitute\%2ofor\%20 Healthcare\%2olnformatics/IHII_Medicines_in_U.S_Report_2011.pdf

87. Smith HS. Opioids and neuropathic pain. Pain Physician 2012; 15:ES93ESilo.

88. National Alliance for Model State Drug Laws. State Statutes and Regulations Relative to Chronic Pain and Pain Management. June 2012. www.namsdl.org/ documents/PainCompilationUpdatedJune2012.pdf

89. Manchikanti L, Damron KS, McManus CD, Barnhill RC. Patterns of illicit drug use and opioid abuse in patients with chronic pain at initial evaluation: A prospective, observational study. Pain Physician 2004; 7:431-437.

90. Manchikanti L, Malla Y, Wargo BW, Fellows $B$. Comparative evaluation of the accuracy of benzodiazepine testing in chronic pain patients utilizing immunoassay with liquid chromatography tandem mass spectrometry (LC/MS/ MS) of urine drug testing. Pain Physician 2011; 14:259-270.

91. Manchikanti L, Malla Y, Wargo BW, Fellows B. Comparative evaluation of the accuracy of immunoassay with liquid chromatography tandem mass spectrometry (LC/MS/MS) of urine drug testing (UDT) opioids and illicit drugs in chronic pain patients. Pain Physician 2011; 14:175-187.

92. Von Korff M, Saunders K, Ray GT, Boudreau D, Campbell C, Merrill J, Sullivan $M$, Rutter $C$, Silverberg MJ, Banta-Green C, Weisner C. De facto longterm opioid therapy for noncancer pain. Clin J Pain 2008; 24:521-527.

93. Pereira J, Lawlor P, Vigano A, Dorgan $M$, Bruera E. Equianalgesic dose ratios for opioids. A critical review and proposals for long-term dosing. J Pain Symptom Manage 2001; 22:672-687. Narcotic analgesic converter, GlobalRPh Inc. www.globalrph.com/narcotic. cgi

94. Bohnert $A S$, Valenstein $M$, Bair $M J$, Ganoczy D, McCarthy JF, Ilgen MA, Blow FC. Association between opioid prescribing patterns and opioid overdose-related deaths. JAMA 2011; 305:1315-1321.

95. Hall AJ, Logan JE, Toblin RL, Kaplan JA, Kraner JC, Bixler D, Crosby AE, Paulozzi 
LJ. Patterns of abuse among unintentional pharmaceutical overdose fatalities. JAMA 2008; 300:2613-2620.

96. Paulozzi LJ, Kilbourne EM, Shah NG, Nolte KB, Desai HA, Landen MG, Harvey $\mathrm{W}$, Loring $\mathrm{LD}$. A history of being prescribed controlled substances and risk of drug overdose death. Pain Med 2012; 13:87-95.

97. Braden JB, Russo J, Fan MY, Martin BC, DeVries A, Sullivan MD. Emergency department visits among recipients of chronic opioid therapy. Arch Intern Med 2010; 170:1425-1432.

98. Gomes T, Juurlink DN, Dhalla IA, Mailis-Gagnon A, Paterson JM, Mamdani MM. Trends in opioid use and dosing among socio-economically disadvantaged patients. Open Med 2011; 5:E13-E22.

99. Dunn KM, Saunders KW, Rutter CM, Banta-Green CJ, Merrill JO, Sullivan $M D$, Weisner $C M$, Silverberg $M J$, Campbell $\mathrm{Cl}$, Psaty BM, Von Korff M.
Overdose and prescribed opioids: Associations among chronic non-cancer pain patients. Ann Intern Med 2010; 152:85-92.

100. Catan T, Perez E. A pain-drug champion has second thoughts. The Wall Street Journal December 17, 2012.

101. Zvolensky MJ, Cougle JR, Bonn-Miller MO, Norberg MM, Johnson K, Kosiba J, Asmundson GJ. Chronic pain and marijuana use among a nationally representative sample of adults. Am J Addict 2011; 20:538-542. 